\title{
The Relationship between Enhancing Efficiency and Reducing Anxiety in the Class during the Assessment
}

\author{
Bajram Demollari ${ }^{1} \&$ Batjar Halili ${ }^{2}$ \\ ${ }^{1}$ University of Prizren, Prizren, Republic of Kosovo \\ ${ }^{2}$ Sakarya University, Adapazari, Turkey \\ Correspondence: Bajram Demollari, University of Prizren, Prizren, Kosovo. Tel: 377-044-19-0658. E-mail: \\ bajra_1985@hotmail.com
}

Received: July 27, 2017

Accepted: September 4, 2017 Online Published: September 6, 2017

doi:10.5539/jel.v7n1p38

URL: https://doi.org/10.5539/jel.v7n1p38

\begin{abstract}
Through this work we suppose to find the relationship between enhancing the efficiency and the circumstance of anxiety in the classroom during the evaluation by the teachers in the Republic of Kosovo, particularly focused in the region of Prizren.

For this study we have researched various approach theories and practices that are close to the topic of investigating.

We have researched the characteristics of evaluation and efficiency of anxiety that appear to students in the Republic of Kosovo; considering that the language of instruction varies from different cultures and contexts of individual and educational students, such as gender, motivation, styles and lessons, years of learning, skills and achievements. The study deals with the strategies used to teach English at high school students, examines the relationship between language learning and anxiety.
\end{abstract}

Keywords: learning strategies, efficiency, anxiety and assessment

\section{Introduction}

\subsection{Theoretical Approach}

Before starting working on this paper, the reason that prompted me of doing this research was my work with the pupils during the period of pupil's assessment at the teaching process. Since our classes have 35 pupils and the effectiveness of the work should be done by high attentiveness of the teacher, because in the process have to be included all the students participating in the class.

However, despite the teacher's attentiveness, the student's comprehensiveness in the process assessment is problematic in the Republic of Kosovo, because the large number of pupils it is a great challenge for the teacher during the evaluation process while for the student it is anxious. That it focuses on the literature research and empirical treatment at the high schools of Prizren, the Republic of Kosovo.

Improving school-based efficiency is a growing concern of education planners and the managers in the recent years (Grauwe, De Anton, \& Naidoo, 2002, p. 18).

The old curriculum of the Republic of Kosovo has incorporated within itself the traditional system where the teacher has been at the main focus of the teaching process. However, the transition from the traditional learning process where the teacher has been on the focus of cooperative teaching process- the pupil has created new situation in the educational process (Bujari \& Remzi, 2010, p. 80).

The focus of attention on strategies used in school functioning, instead of the general education system is inspired by some considerations:

Many reforms in the past tried to focus on isolated componets of the system as only tool for the implementation of the classroom were teachers and texbooks.

Reforms did not fit in with the a lot of different needs of individual schools, characterized by a comprehensive and a wide system strategy. Learning strategy is the key factor that helps determine how and how well our pupils learn the second or foreign language. Learning strategies are difined as specifications, behaviours, steps, or 
techniques such as search for chat partners or encouragement to handle a difficult assignment used by students to encrease their learning (Scarcella, Robin, \& Oxford, 1995, p. 227).

The word strategy comes from the ancient Greek word "strategia", which means steps or actions taken to win a war (Thompson \& Della, 1990, p. 618).

Unfortunately, the combat meaning of the strategy has fallen, but control, purpose and the direct attitude remains in the modern version of the word.

\subsection{Anxiety}

\subsubsection{Language Anxiety}

Language anxiety has been a worldwide problem that is troubling many pupils in most classes of foreign languages. In fact, as the test continues to exist in language classes, the number of students affected by threatening anxiety classes. Researchers have studied the relationship between foreign language anxiety and performance from different perspectives. Noteworthy, one goal has been to review the relationship between anxiety-skills using measures to assess the specific structure of anxiety in foreign languages (Young, 1991, pp. 426-439).

\subsubsection{Test Anxiety}

There are three types of tested students. The first type is that who does not have the study skills or the ability to organize or understand the main ideas for the content that is taught and perhaps its fear of testing results from lack of competence. The second type of anxiety test student possesses the appropriate study skills, but also possesses the "fear of failure" when experiencing appreciation. The third type believes that it possesses qualitative study skills, but in reality it does not (Nitko, 2001, pp. 122-124).

Test anxiety is one of the most important aspects of negative motivation and has poor adverse effects on pupil's performance at school (Hill \& Wigfield, 1984, pp. 105-126).

This is because the students are more susceptible to failure and react more to adult assessment than peer children. Moreover, children with high anxiety have strong motives to avoid criticism and failures, because they are afraid of negative assessment.

\section{Methodology}

\subsection{The Purpose of Research}

The purpose of this study is to examine the teachers' views about the anxiety of tests that are presented to the pupils. The second goal is to gather a sample of exploring strategies that teachers use to support their students that experience test anxiety.

\subsection{Research Hypothesis}

H1. The more you increase teacher's attitudes to control anxiety the proportionality of the pupils for success is higher.

H2. Strategies that are used by the teacher in the Republic of Kosovo are predisposed to negative results of pupils.

H3. Lack of training on psychological aspects makes it impossible to recognize this negative effect on the teacher's side.

\subsection{Population and Sample}

To carry out this research we have selected the pupils of the High Schools of Prizren, Republic of Kosovo, where we have selected four schools of different profiles. The selected schools were: gymnasium of the natural sciences "Gjon Buzuku", the gymnasium of social sciences "Remzi Ademaj", the high school of medicine "Luciano Matroni" and high economic school "Ymer Prizreni". From these schools we have selected five teachers and 151 pupils: 67 girls and 84 boys, aged 17-18 years.

They have been selected pupils with excellent, very good and good success. The reason of selecting these pupils it is because that they are more conscious about their assessment, and also this assessment affects the continuation of their studies. 


\subsection{Methods of Research}

For realization of this research we used the interview and the questionnaires. In the questionnaire we have had 50 questions that have to do with assessing the anxiety of students during the evaluation periods at school subjects. With the interview we have analyzed the problem presented in our research.

\subsection{Analysis of Themes}

Anxiety is a common form of psychopathology that occurs at all stages of life. Often, anxiety can be expanded beyond appropriate developmental levels, interfering with the overall functioning of individuals. Teenagers are often among those who experience the adverse effect of anxiety.

Based on the questions raised in the questionnaire; where the students had to select the answers of the questionnaire with those characteristics that fit their emotional state in relation to anxiety, students have underlined exactly those responses that show their anxiety experience during test assessment. Some of the questions are (Taylor, 1951, pp. 285-290):

\section{6. _ I can not focus at one thing.}

7. _ I constantly notice that my hands tremble when I start testing.

49. _ I withdraw when I face with difficult crises.

43. _ I am inclined to take things with difficulty in assessment, even though I know them.

48. _ Often I feel that I am going to lose my control before the evaluation.

From the total sample of 151 students who attended $100 \%$ of the participants, with 67 girls and 84 boys, affirmed anxiety symptoms in the assessment of 53 girls and 64 boys, with the total number of 117 being symptom of moderate anxiety evaluation. The remaining of the 34 students did not show the symptoms of moderate anxiety.

With the questions that we asked teachers about the strategies they use to reduce student's assessment anxiety, this was shown at the lowest level and the methodology used by teachers for assessment was different. These teachers reported that this inadequate assessment was due to the frequent change from traditional to contemporary learning, lack of training in the field of assessment and psychological managing during sudents' assessment.

From the twenty teachers that we interviewed about the trainings they had completed during last decade, the answer was that they had been trained in using technology in the field of assessment, elementary teaching methods and curriculum development. However, all of this has not been sufficient and had been carried out by non experts of the field, because Kosovo has started with a devastated system. In conclusion, teachers said that for that it was very difficult to implement those bluried knowledge, with the fact that the number of the students was high at classes and the methods of fair evaluation throughout the year were impossible.

\section{Conclusion}

The purpose of this study was to review teachers' strategies for students assessment; which are the strategies to support students who experience anxiety during assessment and what are the anxiety stinging reasons for these students. Based on the interview we conducted with the teachers of four schools, most of them had little knowledge of the new evaluation methodologies and they devoted them to the demostration, provided by the relevant institutions.

Another reason according to the questions submitted to the interview, besides the traing on teaching methodology unquoted unqualified curriculum frameworks, we have lacked trainings for the style of the teacher's leader. These and many other reasons are negative effects that affect students' anxiety assessment: “... teachers said".

In questionnaire realised with pupils for the level of anxiety that they experience, the total number of 151 , that is $100 \%$ of representative sample, 117 of them have shown signs of anxiety in the assessment.

Based on the submitted purpose and the raised hypotheses, the results show that hypotheses raised had been fully verified. 


\section{Acknowledgments}

Supported by the staff of four High Schools of Prizren, Republic of Kosovo.

\section{References}

Bashkim, A., \& Remzi, B. (2013). Bazat e kërkimit në edukim (p. 80). Instituti Pedagogjik i Kosovë.

Grauwe, De Anton, \& Naidoo, P. J. (2002). School Evaluation for Quality improvement (p. 123). UNESCO: International Institute for Educational Planning, Malaysia, Kuala Lumpu.

Hill, T. K., \& Wigfield, A. (Sep., 1984). Test anxiety: A major educational problem and what can be done about it. The Elementary School Journal, 85(1), 105-126. https://doi.org/10.1086/461395

Nitko, J. A. (2001). Educational assessments of students (3rd ed.). Upper Saddle River, Prentice Hall.

Scarcella, R., \& Oxford, L. R. (1992). The Tapestry of Language Learning: The Individual in the Communicative Classroom. Boston: Heinle \& Heinle.

Taylor, J. A. (1951). A personality scale of manifest anxiety. Journal of Abnormal and Social Psychology, 48, 285-290. https://doi.org/10.1037/h0056264

Thompson, D. (1990). Oxford Dictionary (1st ed.). Wordpower.

Young, D. J. (Winter, 1991). Creating a low-anxiety classroom environment: What does language anxiety research suggest? The Modern Language Journal, 75(4), 426-437. https://doi.org/10.1111/j.1540-4781.1991.tb05378.x

\section{Copyrights}

Copyright for this article is retained by the author(s), with first publication rights granted to the journal.

This is an open-access article distributed under the terms and conditions of the Creative Commons Attribution license (http://creativecommons.org/licenses/by/4.0/). 